\title{
Program Kitar Semula: Persepsi Masyarakat Terhadap ReDMac
}

\author{
Ezanee Mohamed Elias*, Zakirah Othman, Norlila Mahidin, Mohd Nasrun Mohd Nawi, Santhirasegaran S.R Nadarajan
}

Pusat Pengajian Pengurusan Teknologi \& Logistik, Kolej Perniagaan, Universiti Utara Malaysia, 06010 Sintok, Kedah, Malaysia

*Corresponding author: ezanee@uum.edu.my

\begin{abstract}
The issue of solid waste management through recycling programs in Malaysia have long been discussed in the mainstream media. However, the issue is still not taken seriously since until today the recycling rate is still low about 11 percent compared to developed countries, which already exceeds 70 percent. The situation is alarming because of its implications on the health and size of landfill is increasingly limited. Therefore, this study aimed to investigate the level of customer awareness campaign supermarkets to recycle through the reward system through the use of automatic machines discharge bottle called Deposited Recycle Machine (ReDMac). Data were collected through a questionnaire and interviews. A number of respondents involved were 362 people and they were randomly selected from five different locations. The study found that $73.2 \%$ of respondents were aware of the recycling campaign held out of which $59.7 \%$ were admitted to participate in the recycling campaign, while $77.1 \%$ of respondents agreed with the reward system to encourage consumers to practice recycling. This study convinced that the best alternative is to recycle plastic bottle through the use ReDMac, as a new way to educate the society to love environmental.
\end{abstract}

Keywords: awareness, bottle, recycle, ReDMac, waste

\section{Abstrak}

Isu pengurusan sisa pepejal melalui program kitar semula di Malaysia telah lama dibincangkan di media arus perdana. Namun begitu, isu ini masih tidak diambil perhatian sewajarnya. Ini kerana kadar kitar semula masih rendah iaitu 11 peratus berbanding negara maju yang sudah melebihi 70 peratus. Keadaan ini semakin membimbangkan kerana implikasinya kepada kesihatan dan keluasan tapak pelupusan sampah yang semakin terhad. Oleh itu, kajian ini bertujuan untuk meninjau tahap kesedaran pelanggan pasar raya terhadap kempen kitar semula melalui sistem pemberian ganjaran menerusi penggunaan mesin pemulangan botal automatik yang dikenali sebagai Recycle Deposited Machine (ReDMac). Data kajian dikumpul melalui soalan kaji selidik dan temubual. Sejumlah responden yang terlibat adalah seramai 362 orang dan mereka dipilih secara rawak dari lima lokasi yang berbeza. Kajian ini mendapati bahawa sebanyak $73.2 \%$ daripada responden menyedari wujudnya kempen kitar semula yang diadakan dan daripada jumlah itu pula 59.7\% mengaku pernah melibatkan diri dalam kempen kitar semula, manakala $77.1 \%$ responden bersetuju dengan sistem pemberian ganjaran dalam menggalakkan pengguna mengamalkan aktiviti kitar semula. Kajian ini menyakinkan bahawa antara alternatif terbaik mengitar semula botal plastik adalah melalui ReDMac, sekaligus mendidik masyarakat cintakan alam sekitar.

Kata kunci: kesedaran, botol, kitar semula, ReDMac, buangan

(C) 2016 Penerbit UTM Press. All rights reserved

\section{口1.0 LATAR BELAKANG}

Pada tahun 1970an, aktiviti kitar semula dianggap sebagai satu pendekatan yang baru dalam melaksanakan proses pembelajaran ke arah masyarakat yang bertolenransi hijau. Namun begitu, aktiviti ini hanya mula dipandang secara serius oleh masyarakat ketika mulai tahun 1990an. Secara umumnya, kitar semula adalah proses yang mengolah bahan-bahan terbuang bagi mendapatkan bahan yang boleh digunapakai semula. Kemunculan pendekatan sedemikian itu telah menjadi satu tuntutan peraturan atau keperluan yang boleh dianggap sebagai tanggungjawab kepada pengeluar dan juga pengilang untuk menghasilkan produk menggunakan bahan mentah yang berasaskan bahan kitar semula seperti kertas, kotak, kaca, dan botol plastik (Boks et al., 1998). Dari sejumlah bahan yang boleh dikitarkan semula, botol plastik adalah bahan utama yang boleh menyebabkan pencemaran alam kerana ianya sukar untuk dilupuskan secara semulajadi. Secara umumnya botol plastik akan mereput secara semulajadi dalam tempoh 400 hingga 450 tahun. Di Malaysia, pembuangan sisa plastik termasuk botol adalah kedua tertinggi iaitu 14\% selepas sisa makanan (45\%) (Hakimi Ismail, 2014).

Justeru itu, sebagai salah satu kaedah yang digunakan untuk mengurangkan pembuangan botol plastik ialah dengan menggunakan mesin pemulangan botol plastik. Mesin ini yang dikenali sebagai Automatic Recycle Deposit Machine (ReDMac) adalah satu mesin yang digunakan untuk memulangkan semula botol plastik. Seterusnya, pengguna mesin ini akan memperolehi bayaran atau ganjaran daripada setiap botol plastik yang telah dipulangkan. ReDMac ini adalah sangat mesra pengguna dan ia berfungsi dengan arahan yang sangat mudah untuk difahami dan dikuti. Disamping itu, mesin ini secara tidak langsung akan mendidik pengguna bagaimana untuk mengasingkan bahan-bahan yang boleh dikitar semula seperti botol plastik, tin aluminium, kertas, kaca dan lain-lain. Dengan itu objektif kajian ini adalah untuk mengkaji tahap kesedaran dan penerimaan pelanggan pasar raya besar (Tesco) terhadap terhadap kitar semula botol minuman berkarbonat plastik (botol plastik). Lantaran itu, objektif kajian ini adalah untuk mengkaji tahap kesedaran pelanggan pasar raya terhadap program kitar semula. Kajian ini juga untuk mengetahui tahap penerimaan mereka terhadap kenaikan harga botol plastik yang akan menggunakan ReDMac dan 
tahap penerimaan teknologi baru dalam program kitar semula. Teknologi ini sudah lama diguna pakai di luar negara seperti di Norway, Sweden dan United Kingdom malah sudah menjadi sebahagian daripada budaya mereka.

\section{口2.0 SOROTAN KAJIAN}

Program kitar semula mula diperkenalkan di Malaysia pada tahun 1993 dengan kemunculan tong sampah berwarna. Namun sehingga kini kesedaran masyarakat terhadap program tersebut masih lagi ditahap yang rendah iaitu kira-kira $11 \%$ berbanding dengan negara lain iaitu $70 \%$ (Hakimi Ismail, 2014). Sementara kadar kitar semula nasional adalah 10.5 peratus berbanding negara maju yang sudah melebihi 40 peratus (Mona Ahmad, 2015). Program kitar semula akan mencapai matlamatnya jika masyarakat menyokong dan terlibat secara aktif dalam menjayakannya (Kelly et al., 2006). Dalam kajian yang telah dijalankan oleh Schultz et al. (1995), beliau fokus kepada faktor individu yang mempengaruhi tingkahlaku untuk kitar semula. Sejumlah 41 faktor individu telah dikaji termasuk soal sikap, pengalaman, demografi dan personaliti. Secara umumnya, kajian ini mendapati wujud hubungan yang positif di antara kebimbangan individu terhadap alam sekitar dan sikap mereka untuk melakukan kitar semula (Schultz \& Oskamp, 1994).

Beberapa penyelidik yang lain juga berminat dalam kajian tingkahlaku yang membabitkan aktiviti kitar semula telah merumuskan penemuan sebelum ini ke dalam rangka kerja teori. Sebagai contoh, kitar semula sisa pepejal telah dikaji dengan menggunakan Teori Tingkahlaku oleh Azjen (Cheung et al., 1999). Selain daripada itu, Fransson dan Garling (1999) dan Tucker et al. (1998) telah mencadangkan model baru untuk memahami dengan lebih mendalam mengenai kitar semula dan juga tingkahlaku yang bertanggungjawab terhadap alam sekitar. Manakala di Mexico satu kajian telah dijalankan untuk menilai akan kecekapan program kitar semula yang dibuat secara formal dan tidak formal (Ojeda Benitez et al., 2002).

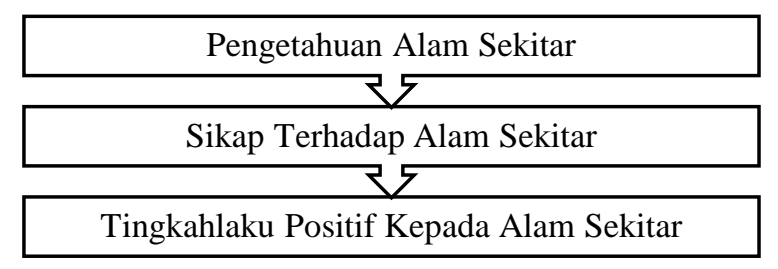

Rajah 1 Model kelakuan terhadap alam sekitar

Penyelidik seperti Kaplowitz dan Levine (2005) berpendapat bahawa masyarakat akan menyertai program kitar semula bergantung kepada tahap pendidikan dan ilmu pengetahuan mengenai implikasi positifnya. Dapatan ini dapat dijelaskan lagi dengan teori yang dikemukakan oleh Kollmus dan Aygeman (2002) yang mengatakan terdapat satu hubungan linear diantara ilmu pengetahuan dan kesedaran terhadap tingkahlaku positif kepada alam sekitar (Lihat Rajah 1). Oleh itu, masyarakat yang mempunyai berpendidikan tinggi kebiasaanya akan lebih cenderung untuk menghargai program kitar semula kerana mereka mempunyai ilmu pengetahuan dan kesedaran serta memahami akan implikasi negatif jika tidak mengamalkannya.

\section{Teori Tingkahlaku Terancang}

Tingkahlaku individu merupakan fokus utama dalam kajian ini. Teori Tingkahlaku Terancang (Theory of Planned Behavioral/TPB) (Ajzen, 1991) dijadikan sumber rujukan utama dalam melihat tingkahlaku para responden terhadap program kitar semula yang menggunakan ReDMac. TPB merupakan satu model yang berdasarkan teoritikal psikologi sosial yang sangat popular dan sering digunakan dalam kajian untuk menerangkan pelbagai situasi tingkahlaku para pengguna. TPB ialah kesinambungan daripada Teori Tindakan Beralasan (Theory of Reasoned Action). Di sini, satu tambahan konstruk kawalan tingkahlaku yang ditambah bertujuan untuk menangani situasi di mana individu tidak mempunyai kawalan sepenuhnya terhadap sesuatu tindakan ataupun tingkahlaku (Zainol \& Kamil, 2009). Berdasarkan teori ini, dapat difahami bahawa niat dalam melaksanakan sesuatu tindakan atau tingkahlaku seperti kitar semula adalah dipengaruhi oleh sikap terhadap sesuatu tingkahlaku, norma-norma subjektif dan juga kawalan tingkahlaku yang ditanggap. Teori Tindakan Beralasan (Azjen \& Fishbein, 1980) pula mencadangkan bahawa keinginan individu dalam melakukan sesuatu tindakan adalah keinginan terus dalam tingkahlaku dan ini terbahagi kepada dua faktor yang utama iaitu sikap dan norma subjektif.

Sikap secara umumnya merujuk kepada keinginan dan juga kecenderungan seseorang individu terhadap sesuatu manakala norma subjektif pula merujuk kepada penglibatan ataupun tekanan yang wujud serta penerimaan terhadap sesuatu tindakan. Walaubagaimanapun, kelakuan seperti ini selalunya terhalang dan dihalang akibat kurangnya peluang untuk berbuat demikian, kekurangan dari segi pendidikan, kekurangan dari segi kemahiran dan juga wujudnya kekangan masa (Liska, 1984). Keadaan kekurangan ini wujud dalam Teori Tindakan Beralasan (TRA) dalam menerangkan mengenai tingkahlaku dan kelakuan seseorang individu terhadap tindakan yang dilakukan oleh mereka (Calvin et al., 2012). Oleh yang demikian, TPB merupakan kesinambungan daripada Teori Tindakan Beralasan dengan menambahkan beberapa pembolehubah untuk membolehkan teori ini diguna pakai pada masa sekarang. Terdapat pembolehubah yang ditambah ke dalam teori ini adalah melihat kawalan tingkahlaku (perceived behavirol control - PBC). PBC merujuk kepada persepsi individual ke atas kebolehan seseorang individu untuk melaksanakan sesuatu tingkahlaku ataupun tindakan (Azjen, 1991). Dalam kajian yang dijalankan oleh Oom Do Valle et al. (2005) merumuskan bahawa PBC mencerminkan dua dimensi utama iaitu: keadaan luaran dan kebolehan individu untuk melihat ataupun menilai.

Dalam konteks kajian terhadap tingkahlaku dalam program kitar semula, dimensi utama yang boleh diterangkan dalam kes kajian ini adalah kemudahan yang sedia ada iaitu ReDMac. Kefahaman dan juga ilmu pengetahuan serta kesedaran akan mempengaruhi tingkahlaku seseorang individu untuk terlibat dan mengetahui program kitar semula yang dijalankan di kawasan tempat tinggal mereka. TPB telah diterima secara meluas dan diterima pakai dalam kajian lepas yang melibatkan perangai, tingkahlaku dan juga tingkahlaku individu. Teori ini juga banyak digunakan sebagai teori teras dalam mengkaji tingkahlaku individu terhadap tingkahlaku kitar semula. Ramai penyelidik 
telah menggunakan TPB untuk mengkaji tingkahlaku yang wujud terhadap program kitar semula (Maria \& Helen, 2008; Zainol \& Kamil, 2009; Sidique et al., 2010; Calvin et al., 2012). Secara umumnya, TPB memberikan impak dan satu titik permulaan yang baik dalam menjalankan kajian ke atas tingkahlaku pengguna terhadap program kitar semula yang dijalankan. Namun Azjen (1991) mencadangkan supaya digunakan pemboleh ubah tambahan untuk meningkatkan kebolehgunaan dalam model ini. Beliau menyatakan bahawa TPB membenarkan penambahan pemboleh ubah iaitu kawalan tingkahlaku untuk menguatkan lagi model sedia ada dan juga untuk menyesuaikan dengan kajian yang dijalankan (Lihat Rajah 2).

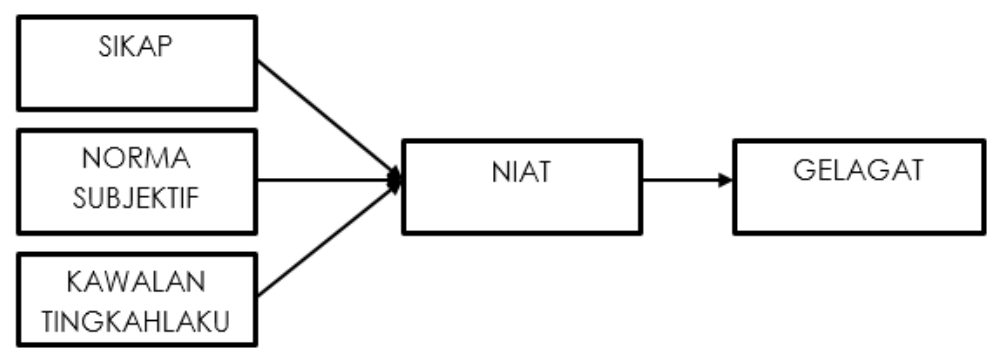

Rajah 2 Teori tingkahlaku terancang (Azjen,1991)

Sikap terhadap tingkahlaku boleh didefinisikan kepada fungsi berkaitan kepercayaan individu terhadap tingkahlaku dan juga evolusi terhadap sesuatu tingkahlaku (Fishbein \& Azjen, 1975). Kepercayaan yang wujud dalam diri individu akan memberikan ilmu pengetahuan dan juga persepsi tehadap sesuatu tingkahlaku. Di dalam kajian ini, sikap yang wujud dalam diri para responden akan memberikan sikap yang lebih cenderung kepada kepercayaan yang ada di dalam diri mereka. Jika seseorang itu percaya bahawa kitar semula dapat membantu dalam memulihkan alam sekitar yang kini mempunyai sumber yang amat terhad dan dapat menjimatkan kos dengan penggunaan semula bahan-bahan yang boleh dikitar semula, mereka akan lebih cenderung untuk menyokong sebarang kempen kitar semula yang dijalankan kerana kepercayaan ataupun sikap mereka yang cenderung ke arah kitar semula. Oleh yang demikian dalam kajian ini, para responden yang tidak dan kurang mempercayai kelebihan yang ada pada kitar semula, mereka akan membantah dan menyatakan bahawa kitar semula tidak memberikan sebarang impak yang positif.

Norma subjektif juga dikenali sebagai tekanan sosial merupakan fungsi jangkaan yang dilihat oleh seseorang terhadap individu ataupun kumpulan yang penting dan juga rapat kepada seseorang. Motivasi seseorang itu akan dipengaruhi oleh perlakuan dan juga tindakan individu atau kumpulan yang rapat dengan mereka (Fishbein \& Azjen, 1975). Kajian lepas telah membuktikan bahawa tekanan oleh individu lain ataupun kumpulan lain menjadi faktor motivasi yang penting kepada tingkahlaku kitar semula (Oskamp et al., 1991; Sidique et al., 2010). Kawalan tingkahlaku dilihat lebih kolektif menjadi faktor yang membina dan juga menghalang prestasi terhadap sesuatu tingkahlaku. Kawalan tingkahlaku dilihat menyediakan satu ukuran yang lebih tepat dalam mengkaji sesuatu tingkahlaku (Davies et al., 2002). Dalam kajian yang dijalankan oleh Tonglet et al. (2004) kawalan tingkahlaku telah dijalankan dengan menggunakan set pemboleh ubah kawalan berunsur tradisional (contohnya: peluang) dan juga faktor yang menyokong ataupun menghalang (contohnya: tahap keselesaan, pengetahuan terhadap kitar semula, apa dan dimana pusat kitar semula). Hasil kajian yang dijalankan, didapati bahawa pengetahuan dan peluang mempunyai kaitan yang ketara dengan keinginan untuk mengitar semula (Helen \& Maria, 2005).

\section{ReDMac}

ReDMac hanya akan membenarkan pelanggan memulangkan botol minuman (plastik atau kaca) yang berdaftar sahaja. Sebagai contoh, botol minuman keluaran F\&N Beverages Marketing Sdn. Bhd dan Permanis Sdn. Bhd yang dijual di pasaraya tertentu sahaja boleh digunakan dalam ReDMac. Sistem ini boleh dilaksanakan oleh pengendali yang diberi tanggungjawab untuk mendaftarkan syarikat pengeluar air minuman sama ada air mineral atau air berkarbonat untuk turut bekerjasama menggunakan ReDMac. Apabila pelanggan memulangkan botol yang berdaftar, sistem akan memeriksa dan mengesahkan apakah jenis botol plastik yang telah dikembalikan. Sistem akan mendaftarkan berapa banyak botol yang telah dipulangkan, apabila pelanggan meminta resit, sistem akan mencetak nilai yang telah ditetapkan dan jumlah deposit yang akan dipulangkan kepada pelanggan dalam bentuk baucer tunai. 


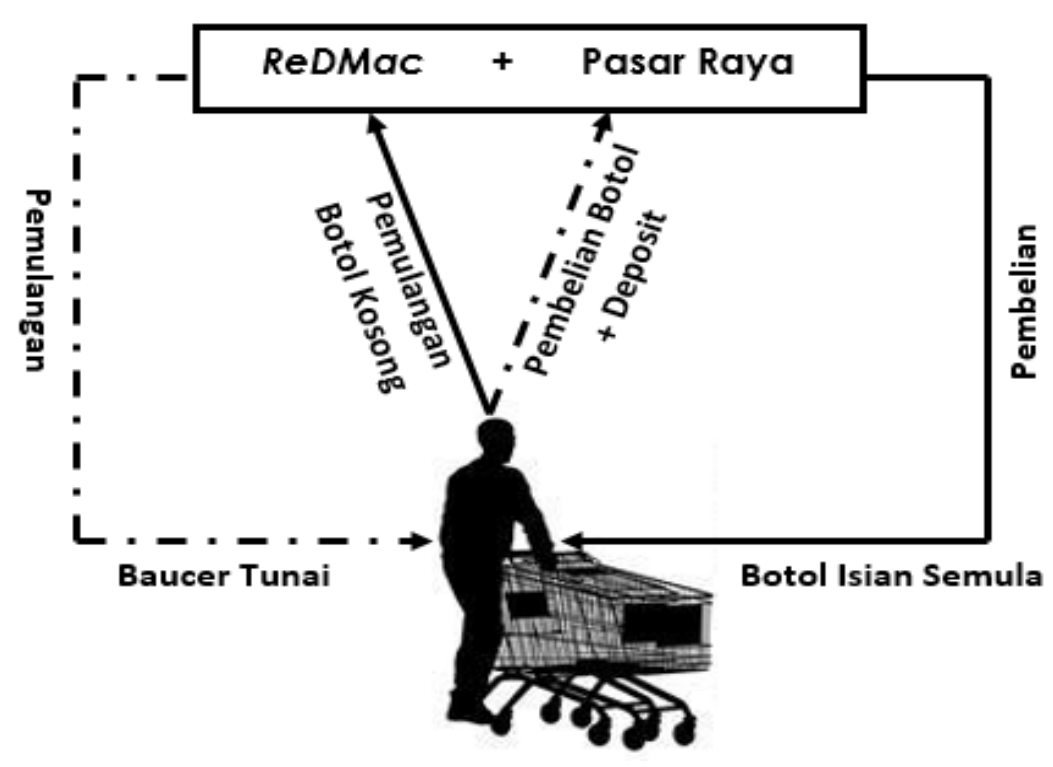

Rajah 3 Proses pembelian dan pemulangan

Rajah 3 di atas menunjukkan penggunaan mesin ReDMac ketika proses pembelian botol minuman dan proses pemulangan. Jika dilihat dalam rajah, terdapat dua jenis anak panah. Anak panah yang mempunyai garis putus-putus bermaksud aliran wang manakala anak panah yang mempunyai garisan penuh bermaksud aliran terhadap botol yang boleh digunakan semula. Proses pertama berlaku ketika para pelanggan melakukan pembelian. Botol minuman yang dibeli oleh pelanggan akan dikenakan sedikit deposit iaitu nilai wang yang setara dengan isi kandungan minuman. Sebagai contoh, botol minuman berisi 1.5 liter akan dikenakan RM0.30. Kemudian apabila pelanggan memulangkan botol tersebut melalui ReDMac, mereka akan mendapat semula deposit yang telah dibayar. Deposit itu diberikan dalam bentuk baucer tunai dan boleh digunakan di pasaraya yang mengambil bahagian dalam program kitar semula. Namun begitu, pemilik baucer berkenaan boleh memilih untuk menggunakannya atau mendermakannya kepada mana-mana persatuan yang berdaftar contohnya Persatuan Bulan Sabit Merah. Bagi pihak pengeluar pula, botol-botol yang tersimpan di dalam ReDMac akan dikutip dan diproses untuk pengisian semula sebelum dijual kembali di pasar raya. Proses ini kebiasaanya akan berulang sehingga empat atau lima kali isian semula sehingga botol tersebut terpaksa dilupuskan.

\section{Teknologi ReDMac}

Penggunaan mesin ReDMac bermula di Norway pada tahun 1962 apabila mesin ini mula direkabentuk oleh syarikat Aage Tveitan. Manakala di Sweden, ianya bermula lebih awal iaitu sekitar tahun 1950an oleh syarikat Wilanders. Kini, mesin pemulangan botol seperti ini amat meluas digunakan di United Kingdom dan negara Eropah seperti Jerman, Belanda dan Peranchis (Lihat Rajah 4). 


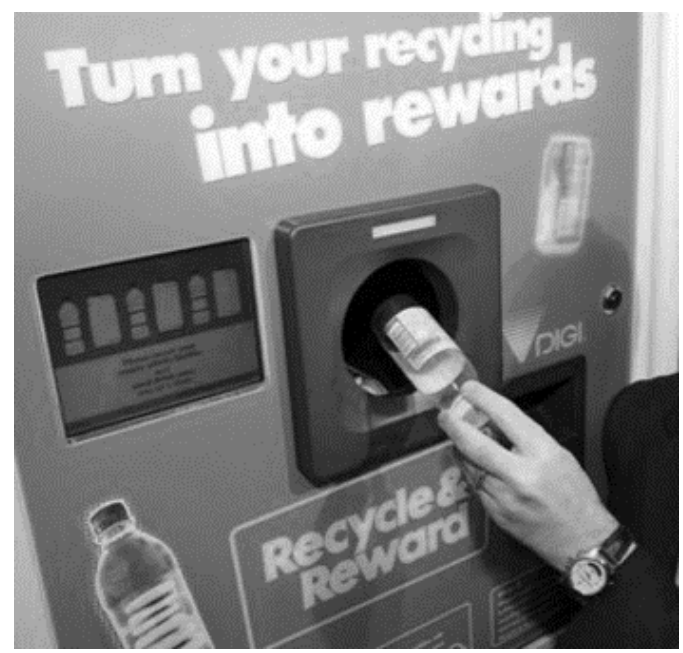

Rajah 4 ReDMac

\section{ロ3.0 METODOLOGI KAJIAN}

Metodologi yang telah digunakan untuk mendapatkan data daripada para responden adalah melalui temubual tidak berstruktur dan soalan kaji selidik. Kaedah temubual dan juga soalan kaji selidik dijalankan secara serentak. Kajian yang dijalankan adalah melibatkan analisa deskriptif. Pengkaji telah memilih lima lokasi ataupun Pasar raya Tesco yang terpilih untuk menjalankan kajian iaitu Tesco Kota Bharu (Kelantan), Tesco Kulai (Johor), Tesco Mergong (Kedah), Tesco Tanjung (Pulau Pinang) dan Tesco Setia Alam (Selangor). Pasar raya Tesco dipilih kerana mereka mempunyai rangkaian yang luas di Malaysia. Di samping itu, Tesco di luar negara misalnya di United Kingdom, mereka telah lama mempraktiskan kitar semula melalui ReDMAc. Sampel kajian akan melibatkan pelanggan yang memasuki Tesco yang terpilih secara rawak. Tempoh dapatan kajian ini hanya berlangsung selama sebulan sahaja. Dalam kajian ini, instrumen utama yang digunakan adalah menggunakan teori yang dibangunkan oleh Azjen (1991) dan telah diadaptasikan oleh Bezzina dan Dimech (2011) iaitu dalam kajian yang telah dijalankan di Malta. Dalan kajian ini, soalan telah dibahagikan kepada beberapa bahagian, iaitu demografik, kesedaran dan penerimaan.

Bahagian kesedaran memberikan fokus kepada kesedaran pelanggan yang ingin dikaji terhadap program kitar semula yang dijalankan di dalam negara. Bahagian ini mempunyai tiga item soalan sahaja. Soalan yang ditanyakan adalah seperti adakah mereka sedar terhadap sebarang kempen kitar semula yang dijalankan, adakah mereka pernah terlibat dalam kempen tersebut dan adakah mereka menyedari mengenai simbol kitar semula yang diletakkan dalam iklan dan juga produk. Dalam kajian ini, penyelidik menggunakan kaedah analisa deskriptif dengan menggunakan IBM SPSS Statistical versi 21. Kaedah ini digunakan bagi mendapatkan frekuensi, peratusan dan min profil seperti umur, jantina, tahap pendidikan, jenis pekerjaan, pendapatan dan lain-lain. Ia juga digunakan untuk mendapatkan frekuensi dan peratusan dalam setiap persoalan yang diajukan dalam soalan kaji selidik yang diberikan. Min merupakan pengukuran deskriptif yang baik bagi menentukan pemusatan hasil dapatan di mana penskoran dalam sesuatu taburan dapatan akan memberikan kesan kepada min (Healy, 2005).

\subsection{ANALISIS DAPATAN KAJIAN}

Secara keseluruhannya dapat dibuat rumusan bahawa kajian ini merupakan satu kajian awal untuk melihat tahap kesedaran dan persepsi pelanggan terhadap program kitar semula yang dijalankan di dalam negara. Selain daripada itu, kajian ini juga memfokuskan kepada tahap penerimaan masyarakat terhadap penggunaan ReDMac dan kenaikan harga yang akan berlaku terhadap produk yang telah dikitar semula. Analisis dapatan kajian ini dibahagikan kepada tiga bahagian iaitu demografi, tahap kesedaran dan tahap penerimaan.

\section{Demografi}

Keseluruhan responden yang terlibat dalam kajian ini adalah berjumlah 362 orang. Hasil dapatan menunjukkan lingkungan umur yang bersetuju untuk terlibat dalam kajian ini adalah individu yang berumur di antara 26 hingga 35 tahun. Penglibatan golongan yang berumur di bawah 15 tahun adalah yang paling sedikit iaitu seramai 16 orang sahaja. Seramai 208 wanita terlibat dalam kajian ini. Seterusnya, dari segi tahap pendidikan menunjukkan majoriti responden adalah lulusan universiti iaitu seramai 234 orang. Selebihnya pula adalah berkelulusan peringkat sijil persekolahan dan juga sijil pusat kemahiran seperti Kolej Komuniti dan Pusat Giat Mara. Kalangan lulusan universiti lebih mudah didekati kerana mereka mungkin sudah biasa menjawab soalan kajian atau pernah terlibat dalam kajian-kajian yang lain.

Dari segi pekerjaan pula, hampir separuh daripada responden adalah bekerja di sektor swasta. Ini adalah kerana kajian dilakukan pada hujung minggu (Jumaat, Sabtu \& Ahad), dan pada waktu itu kebanyakan mereka selalu membeli-belah di Pasar Raya Tesco. Majoriti daripada responden adalah berpendapatan dalam lingkungan RM1,500 hingga RM4,500 sebulan. Jika dilihat dari segi pendapatan, Pasar Raya Tesco merupakan tempat yang sesuai untuk golongan yang berpendapatan dalam lingkungan ini kerana di Tesco, mereka menawarkan harga yang amat berpatutan berbanding dengan harga di luar atau di tempat lain. Oleh kerana lokasi pasar raya Tesco terletak di kawasan bandar, seramai 199 responden (55\%) tinggal di kawasan bandar. Masyarakat yang tinggal di kawasan ini juga dilihat amat prihatin dengan masalah sampah sarap dan mereka juga memberikan pelbagai pendapat mengenai program kitar semula. Selain itu, salah satu faktor yang 
dilihat mengapa masyarakat bandar lebih prihatin terhadap program kitar semula adalah kerana kebanyakan program kitar semula dilancarkan di kawasan bandar.

\section{Tahap Kesedaran Masyarakat Terhadap Program Kitar Semula}

Hasil dapatan kajian mendapati seramai 265 orang responden atau bersamaan dengan $73.2 \%$ daripada responden yang sedar dengan kewujudan program kitar semula. Namun begitu, hanya 216 orang responden atau bersamaan 59.7\% sahaja yang pernah terlibat dengan kempen kitar semula. Tahap penglibatan responden dalam program kitar semula masih lagi dalam kategori yang rendah. Antara reaksi dan alasan yang diberikan oleh mereka yang tidak mahu melibatkan diri adalah kerana mereka melihat peranan pihak kerajaan yang agak tidak serius. Ini juga kerana mereka berasa tidak yakin dengan program seperti itu disebabkan keadaan akan kembali seperti biasa selepas program kitar semula berakhir. Hasil dapatan yang seterusnya dalam kajian ini adalah mengenai simbol kitar semula. Berdasarkan hasil yang diperolehi didapati seramai 299 orang atau bersamaan dengan 82.6\% yang pernah melihat dan menyedari kehadiran logo kitar semula. Perkara ini adalah amat positif kerana mereka sedar dengan logo-logo kitar semula yang diletakkan pada poster mahupun pada produkproduk yang mereka beli. Namun begitu, untuk melakukan mengasingkan sisa-sisa pepejal masih lagi tidak mendapat sambutan yang baik. Secara keseluruhan, hanya 69 responden atau 19\% sahaja yang mempunyai iltizam melakukan aktiviti 3R (reuse, refill \& recycle).

\section{Tahap Penerimaan Terhadap Kenaikan Harga}

Secara keseluruhannya, didapati jumlah kenaikan harga mempengaruhi tahap penerimaan responden. Walaupun pada mulanya kenaikan harga tidak dapat diterima (59.1\%), akan tetapi kenaikan yang minimum masih lagi dapat diterima kerana berdasarkan teknologi ReDMac yang tidak wujud lagi di Malaysia. Persepsi mereka juga agak teruja kerana ingin mengalami sendiri pengalaman melakukan akitiviti bersama ReDMac. Disamping itu, apa bila mengetahui bahawa kenaikan harga berlaku hanyalah sebagai deposit, kebanyakkan dari mereka berasa tidak terbeban. Mereka memahami bahawa pemulangan deposit yang mereka bayar akan berada dalam bentuk baucer tunai yang boleh digunakan untuk membeli pelbagai produk lain.

\section{Potensi Penerimaan Pemindahan Teknologi}

Hasil kajian mendapati hanya 56 orang iaitu mewakili hanya $15.5 \%$ responden sahaja yang mengetahui mengenai ReDMac. Selebihnya iaitu seramai 306 orang yang mewakili $84.5 \%$ responden tidak pernah tahu atau mendengar mengenai teknologi ini. Perkara ini berlaku kerana teknologi ini masih belum lagi digunakan di Malaysia. Sebilangan kecil responden yang mengetahui teknologi ini berkemungkinan kerana mereka pernah berada di luar negara. Perkara ini memberikan reaksi yang positif kerana mereka yang masih belum mengetahui mengenai teknologi ini dilihat begitu berminat untuk mencuba dan bersedia untuk menerima teknologi baru. Pengenalan teknologi baru dalam mempromosikan kempen kitar semula ini amat penting kerana jika dilihat beberapa tahun kebelakangan ini kempen kitar semula yang menggunakan tong sampah yang berbeza warna dilihat kurang memberikan kesan dan tidak berjaya untuk menarik minat masyarakat dalam mempraktikkan kitar semula.

\section{Penerimaan Sistem Pemberian Ganjaran}

Selain itu, hasil kajian juga menunjukkan seramai 279 orang iaitu sebanyak $77.1 \%$ daripada keseluruhan populasi responden bersetuju bahawa program kitar semula akan mendapat penyertaan masyarakat sekeliling jika program tersebut turut memberikan ganjaran. Ganjaran boleh dijadikan sumber motivasi baru dalam mendorong masyarakat untuk terus-menerus mempraktikkan kitar semula selain daripada untuk kepentingan alam sekitar dan juga masalah lambakan sampah yang semakin teruk. Dalam kajian yang telah dijalankan oleh Thorgesen (1996), beliau mendapati orang ramai sentiasa bertanggapan reaksi dan tingkah laku manusia terhadap alam sekitar khususnya dalam isu kitar semula sebagai satu tanggungjawab moral dan ia menjadi satu kewajipan terutama bagi sektor perindustrian. Begitu juga dengan masyarakat mungkin melihat kitar semula sebagai satu tanggungjawab sosial akan tetapi perasaan ini mula berubah apabila inisiatif pemberian ganjaran diperkenalkan kerana masyarakat mula mengira kos yang perlu mereka tanggung untuk mengitar semula (Elena \& Vesna, 2007). Namun begitu, seramai 42 orang responden (11.6\%) menyatakan bahawa mereka masih tidak pasti sama ada program ini akan berjaya atau tidak walaupun diberikan ganjaran. Ketidakpastian ini mungkin bersandarkan program-program kitar semula sebelum ini yang dilihat kurang memberikan kesan kepada masyarakat.

\section{口5.0 PENUTUP}

Dapatan kajian yang diperolehi menunujukkan mendapati bahawa tahap kesedaran masyarakat terhadap kitar semula berada pada tahap yang agak baik namun begitu tahap penglibatan mereka dalam melaksanakan kitar semula masih lagi dilihat tidak begitu berjaya. Secara keseluruhannya, kajian ini telah menunjukkan hasil dapatan yang amat signifikan, malah turut menjawab segala persoalan yang dikemukakan dan berjaya mencapai objektif yang telah ditetapkan. Kajian ini juga telah menyumbangkan satu hasil kajian akademik yang mengkaji mengenai tahap kesedaran terhadap kitar semula, tahap penerimaan terhadap kenaikan harga yang bakal berlaku terhadap produk yang boleh dikitar semula dan juga melihat potensi yang wujud terhadap perpindahan teknologi dalam kitar semula melalui ReDMac. Peraturan yang dilancarkan pada 1 September 2015 (Akta Pengurusan Sisa Pepejal dan Pembersihan Awam 2012) iaitu pengasingan sisa-sisa pepejal sebenarnya adalah langkah utama untuk masyarakat mula belajar proses kitar semula yang baik untuk ReDMac. Oleh yang demikian, hasil dapatan kajian ini sangat penting kerana sebelum memperkenalkan sesuatu teknologi baru, tahap penerimaan oleh masyarakat harus dikaji dahulu supaya ianya bersesuaian dengan kehendak masyarakat dan mampu mencapai objektif yang telah disasarkan. 


\section{口6.0 PENGHARGAAN}

Terima kasih kepada Kementerian Pengajian Tinggi Malaysia (KPT) dan Pusat Pengurusan Penyelidikan dan Inovasi (RIMC) Univerisiti Utara Malaysia di atas sumbangan dana geran RAGS (S/O12676) dalam merintis merealisasikan kajian ini.

\section{Rujukan}

Ajzen, I. (1991). The Theory of Planned Behavior. Organizational Behavior and Human Decision Processes. 50, $179-211$.

Bezzina, F. H., \& Dimech, S. (2011). Investigating The Determinants Of Recycling Behaviour In Malta. Management of Environmental Quality: An International Journal, 22 (4), 463-485.

Boks, C., Nilsson, J., Masui, K., Rose, C. \& Lee, B. (1998). An International Comparison Of Product End Of Life Scenarios And Legislation For Consumer Electronics. Proceedings Of The International Symposium on Electronics and the Environmennt, Oak Brook.

Calvin W., Ronnie C. \& Geoffrey Q. S. (2012). Recyling Attitude And Behaviour In University Campus: A Case Study in Hong Kong. Emerald Group Publishing Limited, 30 (13/14).

Cheung, S.F., Chan, D. K-S., \& Wong, Z. S-Y. (1999). Reexamining the Theory of Planned Behaviour in Understanding Wastepaper Recycling. Environment and Behaviour, 31 (5), 587-612.

Davies, J., Foxall, G.R. and Pallister, J. (2002). Beyond the Intention-Behaviour Mythology: An Integrated Model Of Recycling. Market Theory Environmental Quality. An International Journal, 18(2), 26-136.

Fishbein, M. and Ajzen, I. (1975). Belief, Attitude, Intention, and Behaviour: An Introduction to Theory and Research, Addison-Wesley, Reading, MA.

Fransson, N., \& Garling, T. (1999). Environmental Concern: Conceptual Definitions, Measurement Methods, and Research Findings. Journal of Environmental Psychology, 19: 369-382.

Hakimi Ismail (2014). Kitar Semula Hanya 10.5 Peratus. Diperolehi pada $20 \quad$ Ogos $2016 . \quad$ Arkib: $14 \quad$ Feb $2014 . \quad$ Daripada http://ww1.utusan.com.my/utusan/Dalam_Negeri/20140214/dn_09/Kitar-semula-hanya-10.5-peratus

Healy, J. (2005). Statistics - A Tool For Social Research. ( $7^{\text {th }}$ ed). USA: Thomson Wadsworth.

Helen A., Maria H., (2005). The Consumer's Changing Role: The Case Of Recycling. Management of Environmental Quality: An International Journal, 16 (1), $77-86$.

Kaplowitz, M.D. \& Levine, R. (2005). How Environmental Knowledge Measures Up at A Big Ten University. Environmental Education Research, 11(2), 143-160.

Kelly, T.C., Mason, I.G. \& Leiss, M.W. (2006). University Community Responses To On-Campus Resources Recycling. Resources Conservation and Recycling, 47(1), 42-55.

Kollmus, A. \& Agyeman, J. (2002). Mind The Gap: Why Do People Act Environmentally And What Are The Barriers To People-Environmental Behavior? Environmental Education Research, 8(3), 239-260

Liska, A.E. (1984). A Critical Examination Of The Causal Structure Of The Attitude-Behaviour Model. Social Psychology Quarterly, $47(1), 61-74$.

Maria H. \& Helen A. (2008). Recycling Calls for Revaluation. Suppy Chain Management: An International Journal, 13/1, 9-15

Mona Ahmad. (2015). Membentuk Minda, Sikap Kelas Pertama Cintakan Kebersihan. bhrencana@bh.com.my

Ojeda-Benitez, S., Armijo-de-Vega, C., \& Ramirez-Barreto, M.E. (2002). Formal and Informal Recovery of Recyclables in Mexicali, Mexico: Handling Alternatives. Resources, Conservation and Recycling, 34: 273-288.

Oom Do Valle, P., Rebelo, E., Reis, E. \& Menezes, J. (2005). Combining Behavioural Theories To Predict Recycling Involvement. Environment and Behaviour, 37(3) 364-96.

Oskamp, S., Harrington, M.J., Edwards, T.C., Sherwood, D.L., Okuda, S.M. \& Swanson, D.C. (1991). Factors Influencing Household Recycling Behaviour. Environment and Behaviour, 23, 494-519.

Sidique, S.F., Lupi, F. \& Joshi, S.V. (2010). The Effects of Behaviour and Attitudes on Drop-off Recycling Activities. Resources, Conservation and Recycling, 54, 16370 .

Thorgersen, J. (1996). Recycling And Morality: A Critical Review Of The Literature. Environmental Behave, 28, 536-558

Tonglet, M., Phillips, P.S. \& Read, A.D. (2004). Using The Theory of Planned Behaviour To Investigate The Determinants Recycling Behaviour: A Case Study From Brixworth, UK. Resources Conservation and Recycling, 41, 191-214

Tucker, P., Murney, G., \& Lamont, J. (1998). Predicting Recycling Scheme Performance: A Process Simulation Approach. Journal of Environmental Management, 53, 31-48.

Zainol, B., \& Kamil, I. (2009). Sikap, Norma Subjektif Dan Kawalan Tingkahlaku Ditanggap Terhadap Niat Tingkahlaku Kepatuhan Zakat Pendapatan Gaji., IJMS, $16(1), 31-55$. 